\title{
Effects of diets of different mixing homogeneity on performance and carcass traits of broilers*
}

\author{
İ. Çiftci ${ }^{1}$ and A. Ercan \\ Department of Animal Science, Faculty of Agriculture, Ankara University \\ 06110 Diskapi- Ankara, Turkey
}

(Received 21 March 2002; revised version 16 September 2002; accepted

\begin{abstract}
In this experiment, the chloride analyses methods for testing mixing homogeneity and effects of diets of different homogeneity on broiler performance were investigated. Two hundred and forty day-old broiler chickens were used in three treatments with four replicates, each of 10 males and 10 females. The experiment was conducted in three feeding phases (starter 0-2, grower 3-5 and finisher $6^{\text {th }}$ week of age) and terminated on day 42 .

According to the results of preliminary mixer evaluation based on values of salt analysis, it was estimated that $0.20,0.59$, and 3.75 min mixing times were required for CVs of $>20,20$ to 10 and $<10 \%$ of diet uniformity, respectively. Experimental feeds were produced considering these mixing times. Chloride analysis of samples was performed using titrimetric and Merckquant methods. The correlation between $\mathrm{CVs}$ of the titrimetric and Merckquant chloride test was statistically significant $(\mathrm{r}=0.92, \mathrm{P}=0.0009)$.

No significant differences were obtained among treatments for average liveweight gain, feed intake, feed conversion, mortality, carcass yield and abdominal fat pad percentage. However, CV of final BW was numerically reduced with increase in mixing time.
\end{abstract}

KEY WORDS: diet homogeneity, mixing, $\mathrm{NaCl}$, broilers, performance, carcass

* Supported by Scientific and Technical Research Council of Turkey (TÜBİTAK), Project No VHAG-1395

${ }^{1}$ Corresponding author 


\section{INTRODUCTION}

Mixing is considered to be one of the most critical and essential processes in feed manufacturing. The objective of mixing is to create a completely uniform blend in which all nutrients are distributed uniformly throughout the batch and presented in adequate quantity in the daily feed intake of a target animal. The most common method of testing mixer performance or mixing uniformity is to calculate the $\mathrm{CV} \%$ of a readily analyzable marker or tracer used in the feeds. Salt $(\mathrm{NaCl})$ is a common component of most livestock and poultry diets, therefore sodium or chlorine ions are often used as a mixer test marker. Assaying the salt content of samples may be performed using several techniques such as chemical and test strip methods. The first method is labour- and chemical-intensive and requires highly qualified persons. Second method is simple, fast, time saving and inexpensive. Mixed feed with a CV below $10 \%$ is generally considered to be adequately mixed. Even though the importance of diet uniformity is understood, there is very little credible research relating diet uniformity to animal performance. Duncan (1989) reported that when the CV of protein was increased to 10 or $20 \%$, body weight gain and feed conversion declined. More recently McCoy et al. (1994) conducted research to investigate the effects of mixing uniformity on the growth performance of broiler chickens at adequate and deficient nutrient levels of diets. When diet uniformity was increased from poor (CV of $>40 \%)$ to intermediate (CV of 10-25\%), improvements were noticed in feed conversion for the nutritionally adequate diet, and in body weight gain, feed intake and feed conversion for the nutritionally deficient diet. No further enhanced performance was found as diet uniformity was increased to an adequate level ( $\mathrm{CV}$ of $<10 \%)$.

The objective of this study was to determine the effects of diets of different mixing homogeneity on the performance of broiler chickens. The suitability of salt analysis methods in mixing uniformity tests was also ascertained.

\section{MATERIAL AND METHODS}

\section{Experimental animals}

Two hundred and forty one-day-old Ross PM3 broiler chickens (120 males and 120 females) were randomly allocated to 3 dietary treatments with 4 pens of 20 birds in each pen.

\section{Experimental diets}

Three diets were formulated based on analysis values of feed ingredients to meet or exceed National Research Council (1994) requirements of broiler chic- 
TABLE 1

Compositions of diets, $\mathrm{g} \mathrm{kg}^{-1}$

\begin{tabular}{|c|c|c|c|}
\hline \multirow{2}{*}{ Feed ingredients } & \multicolumn{3}{|c|}{ Diet } \\
\hline & Starter & Grower & Finisher \\
\hline Maize & 531.84 & 536.30 & 567.72 \\
\hline Soyabean meal $(43.19 \% \mathrm{CP})$ & 333.69 & 335.42 & 329.23 \\
\hline Fish meal & 60.00 & 38.21 & - \\
\hline Sunflower oil & 47.50 & 60.00 & 69.84 \\
\hline Limestone & 10.30 & 10.98 & 12.24 \\
\hline Dicalcium phosphate & 6.30 & 8.95 & 12.62 \\
\hline $\mathrm{NaCl}$ & 3.50 & 3.50 & 3.50 \\
\hline Vitamin premix ${ }^{1}$ & 2.50 & 2.50 & 2.50 \\
\hline Mineral premix $^{2}$ & 1.00 & 1.00 & 1.00 \\
\hline DL-Methionine & 2.25 & 2.14 & 1.35 \\
\hline L- Lysine HCL & 0.12 & - & - \\
\hline Coccidiostat $^{3}$ & 1.00 & 1.00 & - \\
\hline \multicolumn{4}{|l|}{ Calculated composition } \\
\hline energy (ME), kcal kg-1 & 3.100 & 3.170 & 3.240 \\
\hline crude protein & 223.0 & 210.0 & 185.0 \\
\hline ether extract & 77.4 & 88.1 & 95.7 \\
\hline $\mathrm{Ca}$ & 10.0 & 9.5 & 8.4 \\
\hline nonphytate $\mathrm{P}$ & 4.5 & 4.2 & 3.5 \\
\hline methionine & 6.6 & 6.1 & 4.6 \\
\hline met.+ cys. & 10.0 & 9.4 & 7.7 \\
\hline lysine & 12.8 & 11.9 & 10.3 \\
\hline tryptophan & 2.8 & 2.7 & 2.4 \\
\hline \multicolumn{4}{|c|}{$\begin{array}{l}{ }^{1} \text { provides per kg of diet: vit. } \mathrm{A}, 12.000 \mathrm{IU} \text {; vit. } \mathrm{D}_{3}, 1.500 \mathrm{IU} \text {; }(\mathrm{mg}) \text { : vit. E, } 50 \text {; vit. } \mathrm{K}_{3}, 5 \text {; vit. } \mathrm{B}_{1}, 3 \text {; vit. } \\
\mathrm{B}_{2}, 6 \text {; vit. } \mathrm{B}_{6}, 5 \text {; vit. } \mathrm{B}_{12}, 0.030 \text {; niacin, } 25 \text {; Ca-D-pantothenate, } 12 \text {; folic acid, } 1 \text {; D-biotin, } 0.05 \text {; choline } \\
\text { chloride, } 400 \text {; apo-carotenoic acid ethyl ester, } 2.5 \\
{ }^{2} \text { provides per kg of diet }(\mathrm{mg}) \text { : } \mathrm{Mn}, 80 ; \mathrm{Fe} 30 ; \mathrm{Zn}, 60 \text {; Cu 5; I, 2; Co, } 0.5 \text {; Se, } 0.15 \\
{ }^{3} \text { Cygro }\end{array}$} \\
\hline
\end{tabular}

kens. The diet compositions are given in Table 1 . The experimental feeds were offered in mash form.

At the beginning of the experiment, the mixer was cleaned, and then mixer evaluation was performed. The mixer is a horizontal double-ribbon mixer with a $200-\mathrm{kg}$ (350 l) full-load capacity, $52 \mathrm{rpm}$, bin and inlet for major and minor ingredients and discharge outlet (Figure 1). The mixer was equipped with a mill, air fan and screen for $700-\mu \mathrm{m}$-particle size. Maize, soyabean meal and fish meal were weighed for $200 \mathrm{~kg}$ mixed feed and placed in the bin of major ingredients. Feed ingredients were placed in the bin individually to avoid mixing in the bin or mill. The mill was started, and then when grinding of feed ingredients was completed, it was 


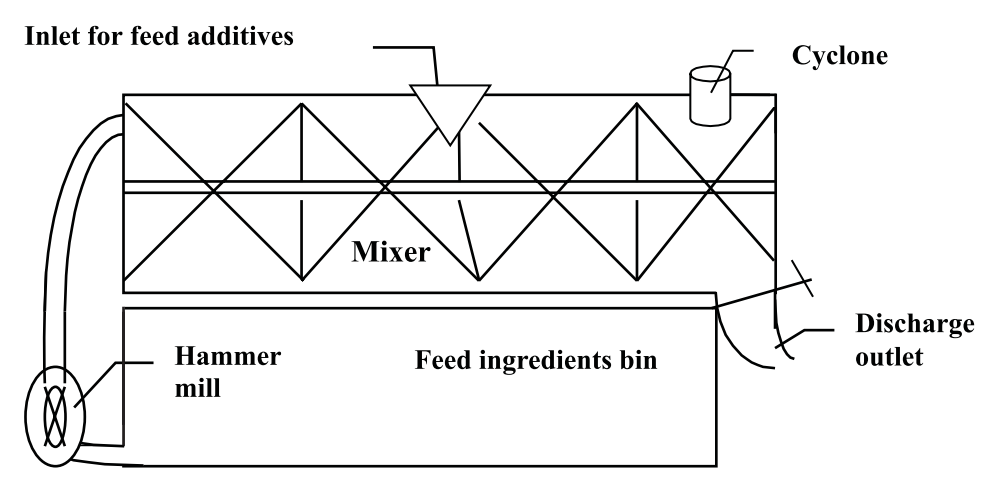

Figure 1. Scheme of the mixer used for production of experimental feeds

stopped. Oil and feed additives were weighed into two small containers, respectively. The mixer was started, and first the oil was added from the inlet of minor ingredients, then feed additives were added. After adding the last ingredient, a timer was started for mixing time, and when the required mixing time was completed, the discharge outlet was opened. The mixing time was started when the last ingredient had been added to the mixer and ended when the mixer began to discharge, therefore it does not include discharging time. Ten feed samples (200 g of each) were taken from the discharge end by a shovel during the bagging in equal time intervals (approximately per $5 \mathrm{~s}$ ) according to previously determined mixer discharge time $(0.75 \mathrm{~min})$. All of the procedures given above were repeated for $0.25,0.50$, $1.0,2.0,4.0$ and $6.0 \mathrm{~min}$ mixing times to estimate the required mixing time to produce the desired diet uniformity for experimental diets. All samples for preliminary mixer evaluation were assayed for salt analysis based on the titrimetric chloride method. Coefficients of variation were calculated from values of salt analysis for different mixing times. It was estimated that $0.20,0.59$ and 3.75 min mixing times were required for $\mathrm{CVs}$ of $>20,20-10$ and $<10 \%$ diet uniformity, respectively. These mixing times were used to produce the experimental diets, and the same procedures as in preliminary mixer evaluation were also employed.

\section{Chemical analyses}

Feed ingredients and diet samples were ground in a sample mill to pass a $0.5-\mathrm{mm}$ screen and were analysed for crude protein, crude fibre, ether extract and crude ash according to AOAC (1990). Analysis of salt in diet samples was performed as described by Mohr (Kolthaff and Kuroda, 1951; Aky1ldı, 1984) for titrimetric and by Anonymous (1999) for the Merckquant chloride test with some modifications. For the Merckquant chloride test, from 0.10 to $0.60 \%$ salt solutions with increasing $0.025 \%$ increments were prepared with distilled water and pure salt. Reaction zo- 
nes of the test strip used to determine salt values of feed samples were compared with the colour pattern of test strips of standard salt solution. The titrimetric and Merckquant chloride tests were performed in two parallel series for each sample. The CVs of the experimental diets were calculated for both salt test methods.

\section{Management and experimental procedures}

Broiler chickens were reared on wooden litter in pens, $2 \mathrm{~m}^{2}$ each. The temperature in the pens was maintained at $32{ }^{\circ} \mathrm{C}$ for week $1,29^{\circ} \mathrm{C}$ for week 2 , and $26^{\circ} \mathrm{C}$ for week 3 of the experiment. After week 3 , the heating fan system was closed, and the house was sufficiently ventilated. Light was provided $24 \mathrm{~h} /$ day. Feeds in suspended plastic feeders and water in automatic drinkers were accessed ad libitum by the chickens. Body weight (BW) and feed intake were measured per pen weekly. Dead chickens were recorded daily and mortality was corrected for when calculating feed intake.

At 44 days of age, all chickens were fasted overnight and weighed. Four chickens ( 2 females, 2 males) closest to the average pen weight were selected, weighed, leg-banded and slaughtered with a knife that severed the jugular vein and allowed to bleed for approximately $3 \mathrm{~min}$. Weights of hot carcass and abdominal fat pad were recorded.

Uniformity of body weight on day 42 was estimated separately for female and male chickens per pen.

\section{Statistical analyses}

Statistical analysis were performed using the ANOVA with repeated model of Statistica software (Statistica, 1984). Responses were also characterized as linear or quadratic using polynomial regression.

\section{RESULTS}

The mean salt values, standard deviations and CVs of diet homogeneity based on titrimetric and Merckquant chloride tests for starter, grower and finisher diets are given in Table 2. The Merckquant chloride test showed lower salt values than the titrimetric salt analysis method for 0.20 and 0.59 min mixing times in grower and finisher feeds, and also for $3.75 \mathrm{~min}$ in the finisher diet $(\mathrm{P}<0.001)$. Mean salt values of feeds for the three feeding phases were also lower $(0.342$ vs $0.482 \%)$ for the Merckquant chloride test for the titrimetric salt analysis method $(\mathrm{P}<0.001)$. As in the results of preliminary mixer evaluation, when the mixing time was increased from 0.20 to $3.75 \mathrm{~min}$, generally lower CV (better diet uniformity) was established. However, improvement of diet uniformity was achieved with only 0.59 
TABLE 2

Effects of mixing time on salt values, standard deviations and CVs in experimental diets measured by titrimetric and Merckquant tests



TABLE 3

Effects of diet uniformity on performance, carcass traits and abdominal fat pad in broiler chickens

\begin{tabular}{lcccc}
\hline & \multicolumn{3}{c}{ Mixing time, min } & \multirow{2}{*}{ SEM } \\
\cline { 2 - 4 } & 0.20 & 0.59 & 3.75 & \\
\hline Week, 0-6 & & & & \\
$\quad$ body weight gain, g & 2167.6 & 2191.0 & 2177.7 & 28.7 \\
feed intake, g & 4131.7 & 4213.0 & 4067.1 & 69.9 \\
FCR, g g-1 & 1.906 & 1.923 & 1.869 & 0.024 \\
mortality, \% & 5.00 & 6.25 & 3.75 & \\
& & & & \\
CV of 6 & & & & \\
male wk BW, \% & 9.50 & 8.10 & 7.41 & \\
female & 10.29 & 9.55 & 7.53 & \\
& & & & \\
Slaughter yield & & & & \\
$\quad$ slaughter weight, g & 2352 & 2387 & 2359 & 0.3 \\
$\quad$ carcass yield, \% & 73.4 & 73.6 & 73.3 & 0.14 \\
$\quad$ abdominal fat, \%BW & 1.46 & 1.50 & 1.44 & \\
\hline
\end{tabular}

all relationships between measured performance traits and mixing time were not significant

min of mixing time based on titrimetric salt analysis for starter and finisher diets and based on the Merckquant chloride test for grower and finisher diets, but no further reduction occurred as mixing time was increased. Moreover, $3.75 \mathrm{~min}$ of mixing time was required to get a CV of less than $10 \%$ based on Merckquant for 


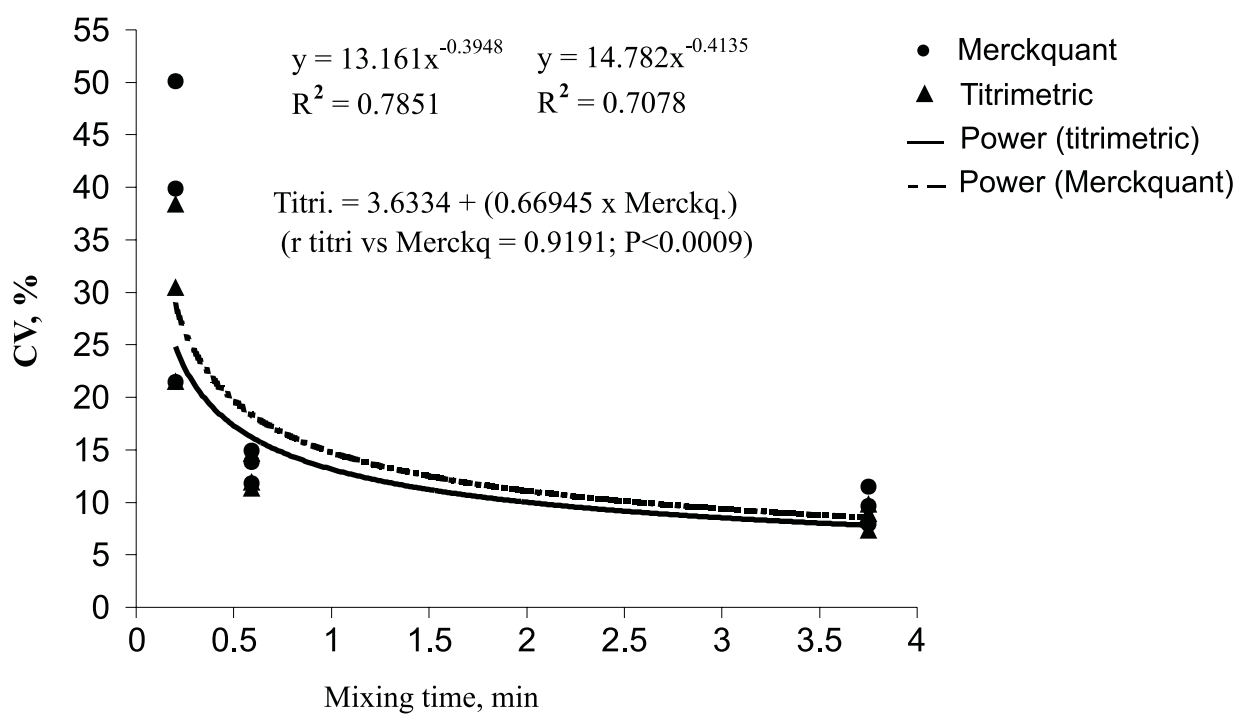

Figure 2. Relationship between diet uniformity (CV) and mixing time (min) and correlation between CVs of salt analysis methods

the starter and on titrimetric salt analysis for the grower diet. Values of CV in starter and finisher diets were determined as 39.89 and $21.44 \%$ for $0.20 \mathrm{~min}$ of mixing time, respectively. The relationship between diet uniformity $(\mathrm{CV})$ and mixing time ( $\mathrm{min}$ ) is given in Figure 2 for both methods. The titrimetric and Merckquant tests showed similar CV linear and non-linear regression equations. The correlations between the $\mathrm{CVs}$ of the titrimetric and Merckquant chloride tests were statistically significant $(\mathrm{r}=0.92, \mathrm{P}=0.0009)$.

Mixing time had no significant effect $(\mathrm{P}>0.05)$ on final body weight, body weight gain, feed intake, feed conversion ratio, mortality, carcass yield and abdominal fat pad for different feeding periods. Uniformity of final body weights was numerically reduced with increasing mixing time for both sexes.

\section{DISCUSSION}

Mean salt values were lower for the Merckquant test than those obtained by the titrimetric method. Both methods have a different analytical basis, so the obtained salt concentrations may be affected. The similar CVs values for both methods with high correlation values indicate that the Merckquant chloride test can be used to determine the mixing uniformity of mixers based on salt analysis. Diet uniformity was improved (CV decreased) with increasing mixing time. Differences of among CVs of phase feeds in the same mixing time may be due to diffe- 
rences of diet compositions. Wilcox and Unruh (1986) and Herman and Behnke (1994) reported that the feed ingredients and their inclusions in the diets affected mixing uniformity.

Increasing mixing time (decreasing CVs) enhanced performance and carcass traits only numerically. This supports the first experimental results of McCoy et al. (1994), who indicated that decreasing CV from 40 or 50 to 10 or $15 \%$ in feeds having National Research Council (1984) recommendations for key nutrients gave only small increases in growth performance of broilers. However, in a second experiment McCoy et al. (1994) found that decreasing CV from 40.5 to $12.1 \%$ in feeds covering only $80 \%$ of nutrient requirements greatly improved performance of broilers. In the present experiment, diets were formulated to meet or exceed the requirements of broilers. It can be concluded that diet uniformity was not critical at the adequate nutrient level, and broiler chickens may tolerate CVs up to $38.36 \%$, but caution should be taken when using medicated, enzyme-supplemented and nutritionally deficient diets.

There are many factors affecting feed mixing uniformity. These factors can be divided into ingredient characteristics (partition of components in the mixture, mass, shape, texture and size of particles, moisture content, electrostatic properties), mixer characteristics (type, poor design, worn, altered or broken equipment, capacity, rpm) and management of mixer (mixing time, filling, cleanness). Although mixing time was considered a major factor in mixing uniformity, other factors also had a marked effect on CV. Therefore, a specified mixing time can not be advisable for all cases - the appropriate mixing time can change as other factors vary. CV should be considered the target for adequate mixing instead of mixing time. Mixer tests are recommended when feed formulation is drastically changed, if the type of ingredients used by the mill are markedly changed, or if further performance improvements are desired.

\section{CONCLUSIONS}

Increasing the mixing time from 0.20 min to 3.75 min reduced $\mathrm{CV}$ to below $10 \%$ based on salt analysis. The Merckquant chloride test may also be used to determine the salt content of feeds and mixing uniformity. Experimental results indicate that increasing CV up to $38.36,30.42$ or $21.46 \%$ for different feeding periods has very small negative effects on the performance and carcass traits of broiler chickens at adequate nutrient levels of diets. In the field, it would be better to consider $10 \% \mathrm{CV}$ for those mixed feeds that have nutrients at the minimum levels. 


\section{REFERENCES}

Aky1ld1z, A.R., 1984. Laboratory Guide for Feedstuffs. Turkish. A.U. Agriculture Faculty Press, Ankara

AOAC, 1990. Association of Official Analytical Chemists, Official Methods of Analysis. $15^{\text {th }}$ Edition. Washington, DC

National Research Council, 1994. Nutrient Requirements of Poultry. $9^{\text {th }}$ revised Edition. National Academy Press. Washington, DC

Anonymous, 1999. Merck Chloride Test. Merck KGaA Darmstadt (Germany)

Duncan M.S., 1989. Strategies to deal with nutrient variability. In: Recent Advances in Animal Protein Production. Monsanto Latin America Technical Symposium Proceedings, pp. 31-40

Hermann T., Behnke K., 1994. Testing mixer performance. Feed Manufacturing. Bull. MF 1172 Revised. Kansas State University. Cooperative Extension Service, Manhattan, KS

Kolthaff I.M., Kuroda P.K., 1951. Determination of traces of chloride. Anal. Chem. 23, 1304-1306

McCoy R.A., Behnke K.C., Hancook J.D., McEllhiney R.R., 1994. Effect of mixing uniformity on broiler chick performance. Poultry Sci. 73, 443-451

Statistica, 1984. Statistica Computer Manuel. StatSoft Inc., Tulsa, OK

Wilcox R.A., Unruh D.L., 1986. Feed manufacturing problems - Feed mixing times and feed mixers. Bull. MF-829, Kansas State University. Cooperative Extension Service, Manhattan, KS

\section{STRESZCZENIE}

\section{Wpływ diet różniących się stopniem jednorodności na wyniki produkcyjne i jakość tuszy broj- lerów}

Badano wpływ stopnia jednorodności diet na wyniki produkcyjne kurcząt brojlerów oraz metod oznaczania chlorków do oceny jednorodności diet. Dwieście czterdzieści jednodniowych kurcząt, podzielonych na 3 grupy, po 4 powtórzenia, liczące po 20 kurcząt (10 kurek i 10 kogutków), żywiono mieszankami starter (0-2 tygodni), grower (3-5 tygodni) i finiszer (6-ty tydzień do ukończenia 42 dnia życia).

Wstępne wyniki dotyczące stopnia wymieszania składników diet, oparte na oznaczaniu chlorków, wykazały, że czas potrzebny do wymieszania wynosi 0,20 ; 0,59 i 3,75 minuty dla uzyskania CV $>20,20$ do 10 i $<10 \%$ jednorodność diety, odpowiednio. Diety doświadczalne przygotowano stosując powyższe czasy ich mieszania. Chlorki oznaczano metodami: miareczkową oraz Merquanta. Korelacja pomiędzy CVs przy oznaczeniu chlorków obydwiema metodami była statystycznie istotna $(\mathrm{r}=0,92, \mathrm{P}=0,0009)$.

Nie stwierdzono istotnych różnic w przyrostach żywej wagi, wykorzystaniu paszy, śmiertelności, wydajności rzeźnej oraz udziale tłuszczu brzusznego pomiędzy kurczętami różnych grup w poszczególnych okresach żywienia. Jednakże, ogólnie stwierdzono poprawę przyrostów żywej wagi i wykorzystania paszy przez kurczęta w miarę przedłużania czasu mieszania składników skarmianych diet (CV obniżone). 